\title{
Mapping of Trace Elements in Coal and Ash Research Based on a Bibliometric Analysis Method Spanning 1971-2017
}

\author{
Liu Yang ${ }^{1}$, Qiqi Wang ${ }^{1}$, Xue Bai ${ }^{2, *}$, Jun Deng ${ }^{1}$ and Yinjie $\mathrm{Hu}^{1}$ \\ 1 College of Geoscience and Surveying Engineering, China University of Mining and Technology (Beijing), \\ Beijing 100083, China; 108889@cumtb.edu.cn (L.Y.); wangqiqi906@gmail.com (Q.W.); \\ dengjun176362@gmail.com (J.D.); huyinjie521@gmail.com (Y.H.) \\ 2 Branch of Resource and Environment, China National Institute of Standardization, Beijing 100191, China \\ * Correspondence: baixue@cnis.gov.cn; Tel.: +86-186-0108-1100
}

Received: 8 December 2017; Accepted: 23 February 2018; Published: 28 February 2018

\begin{abstract}
Coal is the most important fossil energy used in China. The environmental impact of trace elements released in coal combustion has become one of the hottest issues in recent years. Based on a software named CiteSpace, and social network analysis (SNA), a bibliometric analysis of research into trace elements in coal and ash field during 1971-2017 is presented with the information of authors, countries, institutions, journals, hot issues and research trends in the present study. The study results indicate that: (1) Shifeng Dai, Robert B Finkelman, Guijian Liu and James C Hower have a large number of publications with great influence. (2) China (29.8\%) and USA (22.2\%) have high productivity in total publications. China and the USA correlate closely in the cooperative web system. (3) China University of Mining and Technology and Chinese Academy of Sciences take the leading position in the quantity of publications among all research institutions. (4) Energy and fuels, engineering and environmental science are three disciplines with the most studies in this field. (5) International Journal of Coal Geology, Fuel, Energy and Fuels and Fuel Processing Technology are the top four journals with the most publications in this field. (6) The enrichment origin and modes of occurrence of trace elements are the mainstream research related to trace elements in coal and ash. The environmental problems caused by coal combustion have promoted the development of trace elements in coal research, and human health is getting more and more popular in recent years. The study findings provide a better understanding of features of trace elements in coal and ash research, which could be taken as a reference for future studies in this field.
\end{abstract}

Keywords: trace elements; coal; fly ash; bibliometric analysis; CiteSpace

\section{Introduction}

Coal is the fossil fuel with the largest reserves in the earth. It is the major power energy in most countries and an important component of the global energy resources [1]. However, the trace elements released during coal utilization, coal combustion and the toxic elements of combustion products may bring serious environmental hazards, which not only pollute the atmosphere, water environment and soil [2-4], but also have adverse impacts on human health [5-7]. In order to master the characteristics of trace elements in coal research, the study adopts the bibliometric analysis software to analyze the publications panning the time period of 1971-2017 in this field.

At present, there are many software used for bibliometric analysis, such as Bibexcel, NetDraw, SATI, CiteSpace, Pajek and Thomson Data Analyzer (TDA). For example, Zhang et al. adopted Bibexcel and Pajek software to analyze the progress of study on water footprint [8]; Liu et al. used TDA to conduct a statistical analysis on the research status and development trends for sensing and 
control technologies of industrial robots from the viewpoint of patent analysis [9]; Liang et al. applied CiteSpace to analyze the publications of acupuncture and moxibustion [10]. CiteSpace was developed by Chaomei Chen, a scholar from Drexel University of USA, for visualization analysis of scientific publication. Through co-occurrence analysis and co-citation analysis on a large number of relevant publications, it can analyze and predict the development trend of a particular study field, and therefore, it has been applied in many fields [11,12]. CiteSpace supports Chinese and English as well as a variety of data formats. Compared to other publication analysis software, it features a vast processing scale and is capable of presenting more comprehensive and clear bibliometric analysis results [13,14].

Due to the growing public awareness of environmental protection and the significant potential of economic added-values of valuable elements, the research on trace elements in coal and ash has been growing in recent years. The purpose of this study is to investigate the implications of the research in this field from 1971 to 2017 based on the bibliometric technique, CiteSpace software and 1534 publications in this field sourced from the Web of Science database. A general profile of leading countries and institutions, authorships and mainstream journals are recognized by the bibliographic statistics. Furthermore, a summary of the most frequently used keywords obtained from title, author keywords and keywords plus analysis provides the indications of discovering the current research emphases and trends.

\section{Data and Methods}

\subsection{Data Description}

This study adopts all databases in Web of Science as the data sources and applies the advanced search with the sub-formula of TI $($ Title $)=$ coal $^{*}$ AND TS $($ Topic $)=\left(\right.$ trace element ${ }^{*}$ OR harmful element ${ }^{*}$ OR toxic element* OR hazardous element ${ }^{*}$ OR critical element* OR valuable element*). The time span includes 1950-2017 years and there are 2027 records (the date of the searched data is as of 14 January 2018). The articles, reports, presentations in print forms are not included in the present study because of their limited access to readers.

When searching in the Web of Science database, in order to avoid the interference of non-academic and invalid publications on the study results and ensure the precision and comprehensive ratio of trace elements in coal and ash, the search results are assessed and certain documents are eliminated $[15,16]$. Firstly, the information publications are eliminated and the publications from academic journals are selected to ensure the credibility of study results. Secondly, select the publications with keywords for relevant analysis on keywords and terms. After screening, each piece of data is downloaded as the full-record text format, and finally after deduplication treatment, 1724 valid publications are kept, with a time span of 1971-2017, from a total of 47 years.

\subsection{CiteSpace}

The study mainly adopts CiteSpace (5.1.R2 SE), which is a free software provided by IBM HTTP Server. It can be used to analyze the potential knowledge in scientific studies, present the structure, rule and distribution of scientific knowledge in terms of scientific metrology, data and information visualization. It can easily capture the detailed matrix of relations among different objects. The abstract information is shown by means of visual images [17], which do help to strengthen people's awareness. The Centrality and Burst of CiteSpace are two important indicators. The Centrality is used to find out and measure the importance of the term and mark the key point of node in purple circle in the knowledge graph. Burst refers to burst of terms or publications, authors, journals and suddenly added citation information of other node types, which are marked in red in CiteSpace [18]. The TimeLine and TimeZone are two important indicators used to reflect the frontier and the trend. When CiteSpace is adopted to analyze data, in order to make the network graph simple and clear with strong analyzability of centrality, the threshold and parameters are selectively set first [19].

In addition, the study conducts comprehensive analysis mainly on the annual quantity of publications, authors, disciplines, countries, journals, keywords and other aspects. The quantity of publications refers to 
the quantity of academic papers. The quantity of publications regarding trace elements in coal and ash in unit time reflects the study condition, study level and development speed of this field [20]; the study on the author's productivity and contribution could investigate the narrative characteristics of the researchers of the field. It is especially true for the productive authors with great influence, who always support and dominate the development trend of the discipline study. Set the parameters in CiteSpace to conduct co-occurrence and co-citation analysis of the authors, so as to make judgment on the quantity of publications and cooperation extent among authors based on the thickness of node and connection line [21]; conduct social network analysis (SNA) analysis on the countries with a large number of publications to analyze the publications of each country and the year and cooperation extent of the first cooperation between countries. The analysis results of the research institutions can reflect the constitution of the institution which is at the frontier of a specific study field [22]. Compare indicators of TimeLine and Betweenness Centrality of different disciplines to analyze the evolution dynamics of disciplines of a specific field. Analyze the frequently-used keywords, burst of term and frequently-referenced publications to determine the focuses and trends of the study on trace elements in coal and ash [23-25].

\section{Results and Analysis}

\subsection{Publication Type Record}

There are 1724 records regarding studies on trace elements in coal and ash searched based on Web of Science, mainly including paper, meeting proceedings, review, abstract and other publication types. Among them, the paper has the largest proportion, accounting for $86.43 \%$ of all records, followed by meeting minutes (15.78\%), review (3.6\%), abstract (2.03\%), and other types of publications (less than $2 \%$ ). The downloaded data information of text records includes the author, title, year of publication, number of pages, address, author keywords, and countries/territories, institutions, journals, citation and discipline types in Web of Science and so forth.

\subsection{Variation Characteristics of Annual Quantity of Publications}

According to the distribution of annual publications for 2017, the first publication regarding the study on trace elements in coal and ash was found in 1971 in the database with only one publication available in that year. The annual quantity of publications in 28 years from 1971 to 1998 remained stable with a small quantity of less than ten. The study in this field became vibrant since 1999, with rapidly increasing quantity of publications, from six in 1998 to 52 in 1999. It is a pity that the valuable pioneering studies are in print form and have not yet been uploaded onto the internet. The present study could not assess the pioneering studies. From 1999 to 2016, the quantity of publications fluctuated and reached a relatively low point in 2002, 2005 and 2009, but there was an uptrend as a whole, with an average annual growth of eight publications. By 2016, the quantity of publications reached more than 150 and the study became highly vibrant (Figure 1). As there were a small number of publications during 1971-1998, the period of 1999-2017 is selected as the main study period.

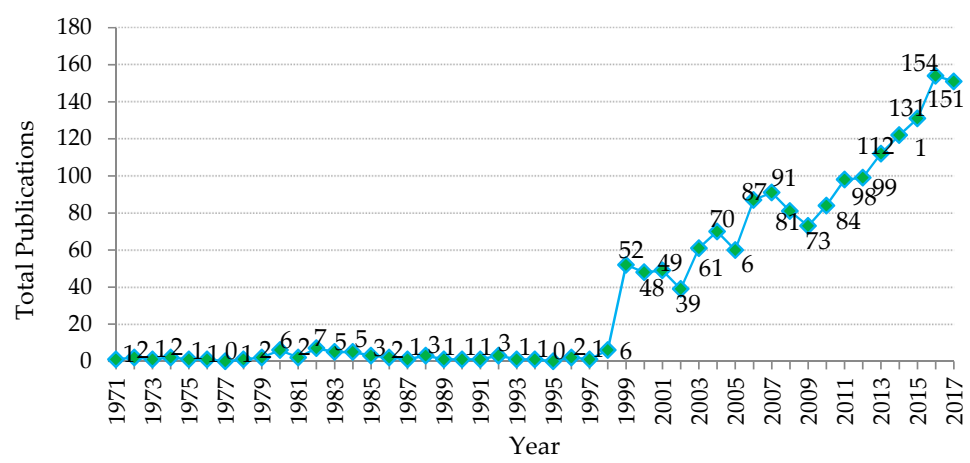

Figure 1. The distribution of publications of trace elements study in coal and ash (1971-2017). 


\subsection{Co-Occurrence and Co-Citation Analysis of Authors}

\subsubsection{Co-Occurrence Analysis of Authors}

The results of the co-occurrence analysis indicate that there is a partial cooperative relationship among the authors (Figure 2). The authors of the study on trace elements in coal and ash with a relatively large number of publications include Guijian Liu (73 publications, China University of Science and Technology), Hower, James C (51 publications, University of Kentucky), Querol, Xavier (49 publications, CSIC), and Shifeng Dai (45 publications, China University of Mining and Technology). In addition, Colin R. Ward (University of New South Wales), Chenlin Chou (Illinois State Geological Survey) and Chaochao Zhou (China University of Mining and Technology) are productive authors (more than 25 publications). The ranking of centrality is as follows: Liu G.J. (0.16), Dai S.F. (0.14), Chou C.L. (0.14), Ren D.Y. (0.12), and Wang J. (0.08) (Table 1). The Top 5 authors have publications with great influence and comparatively obvious purple marks in the outer circle of the corresponding nodes in the graph (Figure 2); the cooperation among the productive authors is relatively close, such as Liu G.J. and Chou C.L., Zhou C.C., Sun R.Y. et al., and Dai S.F. and Hower J.C., Ward C.R., Chou C.L., Ren D.Y. et al.; Liu G.J., Dai S.F., Chou C.L., Querol X., Ward C.R. have obvious red marks (Figure 2), which indicates that they have a burst of terms with relatively great influence and high level of attention in a certain period of the study process.

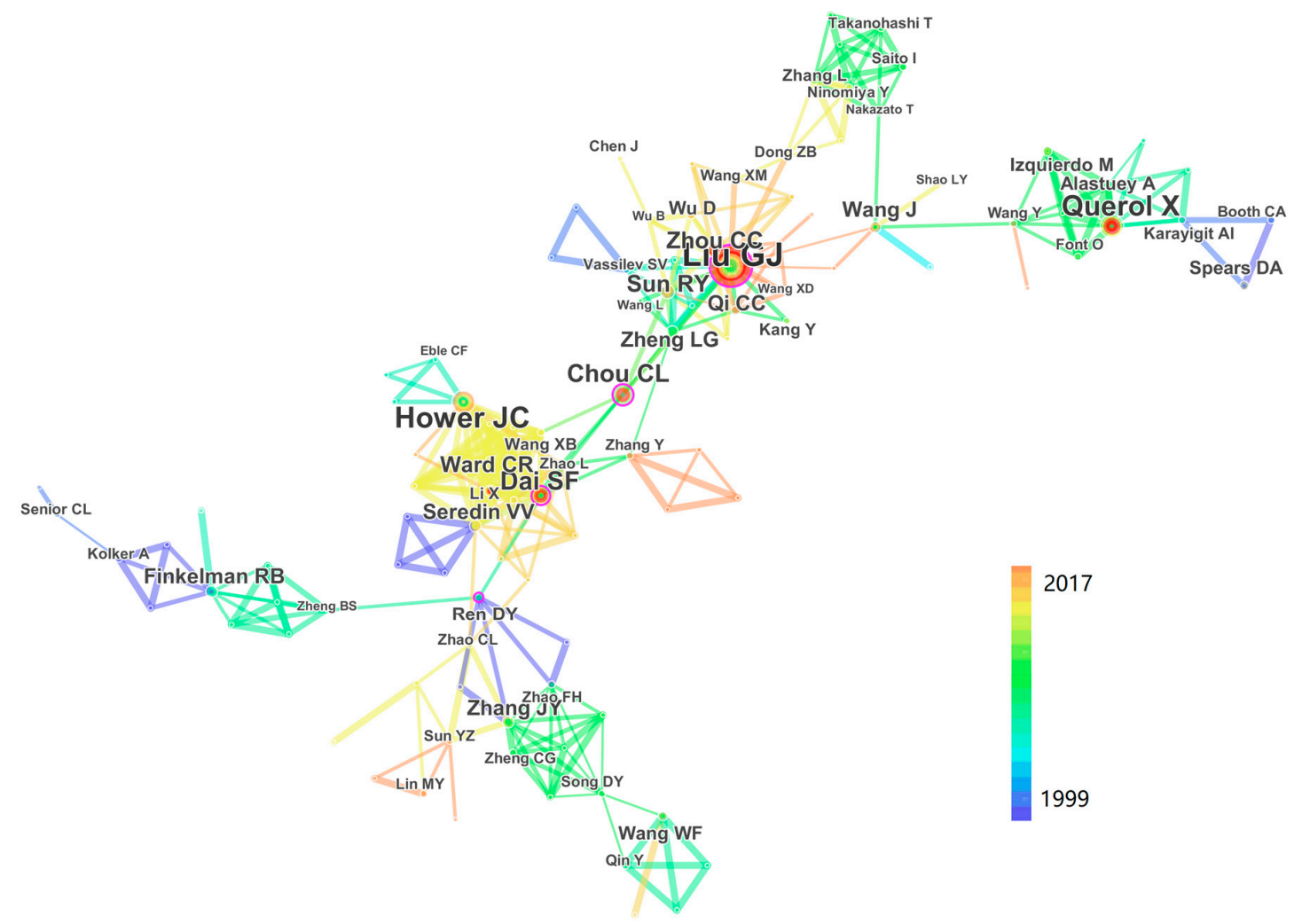

Figure 2. The co-occurrence of productive authors of trace elements in coal and ash. The different colors display the different year of the first cooperation between the authors. The size of the pot displays the number of cooperative studies of co-occurrence authors. 
Table 1. Information of productive authors of trace elements in coal and ash.

\begin{tabular}{cccc}
\hline No. & Author & TP & Centrality \\
\hline 1 & Liu G.J. & 73 & 0.16 \\
2 & Hower J.C. & 51 & 0.02 \\
3 & Querol X. & 49 & 0.01 \\
4 & Dai S.F. & 45 & 0.14 \\
5 & Ward C.R. & 34 & 0.00 \\
6 & Chou C.L. & 30 & 0.14 \\
7 & Zhou C.C. & 25 & 0.00 \\
8 & Zhang J.Y. & 24 & 0.04 \\
9 & Sun R.Y. & 23 & 0.01 \\
10 & Martinez-Tarazona M.R. & 22 & 0.00 \\
10 & Wang X.B. & 22 & 0.02 \\
\hline \multicolumn{4}{c}{}
\end{tabular}

\subsubsection{Co-Citation Analysis of Authors}

The co-citation analysis results of authors indicate that top five authors with the highest cited frequency include Finkelman R.B. (244), Swaine D.J. (221), Querol X. (202), Dai S.F. (162) and Goodarzi F. (138); those with relatively high centrality are Goodarzi F., Senior C.L., Querol X., Bouska V., Kukier U., Finkelman R.B. et al. (Table 2). The study finds out that some authors (such as Finkelman R.B.) have a comparatively small number of publications, high cited frequency and large centrality, which indicates that the term about study on trace elements in coal and ash of the author is comparatively hot, with relatively great influence and high level of attention. Moreover, some authors (such as Goodarzi F.) have strong bursts and their publications have relatively high levels of attention in a certain period. The influence of the author on the study on trace elements in coal and ash should not be determined by the quantity of publications alone.

Table 2. Information of highly cited authors of trace elements in coal and ash.

\begin{tabular}{ccccc}
\hline Author & CF & Centrality & Burst & THCP \\
\hline Finkelman R.B. & 244 & 0.08 & - & Finkelman R.B., 2012, INT J COAL GEOL, V94, P3 \\
Swaine D.J. & 221 & 0.04 & - & Swaine D.J., 2000, FUEL PROCESSING TECHNOL, V65, P21 \\
Querol X. & 202 & 0.10 & - & Querol X., 2012, INT J COAL GEOL, V94, P54 \\
Dai S.F. & 162 & 0.02 & 15.8 & Dai S.F., 2012, INT J COAL GEOL, V94, P3 \\
Goodarzi F. & 138 & 0.13 & 3.62 & Goodarzi F., 2002, FUEL, V81, P1199 \\
Hower J.C. & 131 & 0.07 & - & Hower J.C., 2010, PROG ENERGY COMBUST SCI, V36, P510 \\
Huggins F.E & 128 & 0.06 & - & Huggins F.E., 2002, INT J COAL GEOL, V50, P169 \\
Vassilev S.V. & 108 & 0.05 & - & Vassilev S.V., 2007, FUEL, V86, P1490 \\
Ward C.R. & 103 & 0.03 & - & Ward C.R., 2012, INT J COAL GEOL, V94, P250 \\
Spears D.A. & 99 & 0.03 & - & Spears D.A., 1999, FUEL, V78, P1671 \\
Yudovich Y.E. & 99 & 0.03 & - & Yudovich Y.E., 2009, INT J COAL GEOL, V78, P135 \\
\hline & \multicolumn{4}{c}{ CF: Cited Frequency; THCP: Highest Cited Publications. }
\end{tabular}

\subsection{Distribution of Countries/Territories and Institutions}

The analysis results indicate that China $(513,29.8 \%)$ and USA $(381,22.2 \%)$ are two leading countries with many more publications than other countries, followed by India $(112,6.5 \%)$, Spain $(112,6.5 \%)$ and Australia (93,5.4\%) (Table 3). Apparently, China and USA have the largest nodes and the greatest contributions to the quantity of publications. From the colors of lines connecting different nodes, England, USA, Spain and Turkey have established a cooperative relationship long time ago, and England and Turkey have established a very close cooperative relationship earlier (Figure 3). From the thickness of lines, Spain has close cooperative relations with Greece, Brazil and Bulgaria; Germany has more cooperation with Brazil and Serbia. The cooperation relationship among all countries involved is relatively close. From the knowledge graph, some countries have a small number of publications (such 
as Australia) but strong centrality of node and large nodes displayed on the knowledge graph (Figure 3), indicating that the publications of these countries have great influence; USA, Japan and China have strong burst, indicating that they have study achievements attracting comparatively great attention in a certain period. The top 5 countries with the strongest node centrality include Australia (0.57), USA (0.39), Spain (0.31), England (0.29) and China (0.25) (Table 3). The publications of these countries have comparatively great overall influence.

In terms of the publications from 1971 to 2017, China University of Mining and Technology and Chinese Academy of Sciences are most productive institutions in this study field, accounting for more than $7 \%$ of the total publications, followed by Consejo Superior de Investigaciones Cientificas, CSIC, University of Science and Technology of China, University of Kentucky, Institution of earth environment, CAS, Council of Scientific and Industrial Research India and so forth (Figure 4). Among them, China University of Mining and Technology, University of Kentucky and Chinese Academy of Sciences have the strongest centrality (Figure 5), indicating that these institutions have strong influence in the field of trace elements in coal and ash. USGS and University of New South Wales have the strongest burst, indicating that their study results about the trace elements in coal and ash in a certain period of the study received sudden attention. The institutions with more publications and greater influence mainly consist of universities and research institutes, which ensure the level of study on trace elements in coal and ash to some extent, and correspond to their countries with high production.

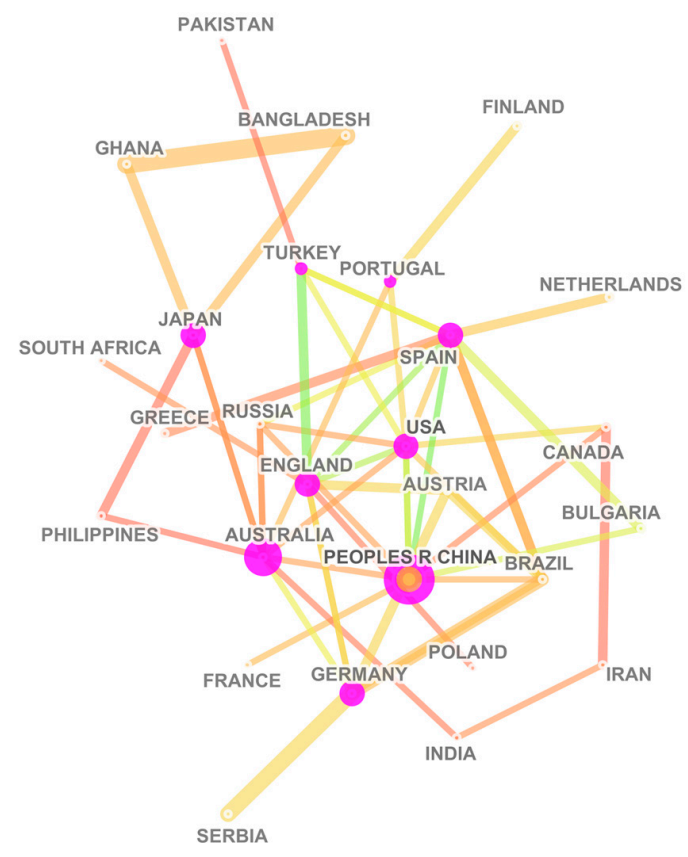

Figure 3. The cooperation network of the productive countries/territories of trace elements in coal and ash.

Table 3. Contribution of the top 16 productive countries/territories of trace elements in coal and ash during 1971-2017.

\begin{tabular}{cccc}
\hline Country & TP & R (\%) & Centrality \\
\hline China & 513 & $1(29.77)$ & 0.25 \\
USA & 381 & $2(22.10)$ & 0.39 \\
Spain & 112 & $3(6.50)$ & 0.31 \\
India & 112 & $3(6.50)$ & 0.04 \\
Australia & 93 & $4(5.40)$ & 0.57 \\
Russia & 72 & $5(4.18)$ & 0.03 \\
Brazil & 67 & $6(3.89)$ & 0.07 \\
Japan & 65 & $7(3.77)$ & 0.22 \\
England & 65 & $7(3.77)$ & 0.29 \\
\hline
\end{tabular}


Table 3. Cont.

\begin{tabular}{cccc}
\hline Country & TP & R (\%) & Centrality \\
\hline Turkey & 60 & $8(3.48)$ & 0.11 \\
Poland & 59 & $9(3.42)$ & 0.00 \\
Canada & 52 & $10(3.02)$ & 0.07 \\
South Africa & 41 & $11(2.38)$ & 0.00 \\
Bulgaria & 31 & $12(1.80)$ & 0.00 \\
Germany & 30 & $13(1.74)$ & 0.20
\end{tabular}

TP: Total publications; R (\%): Rank and the percentage of total publication.

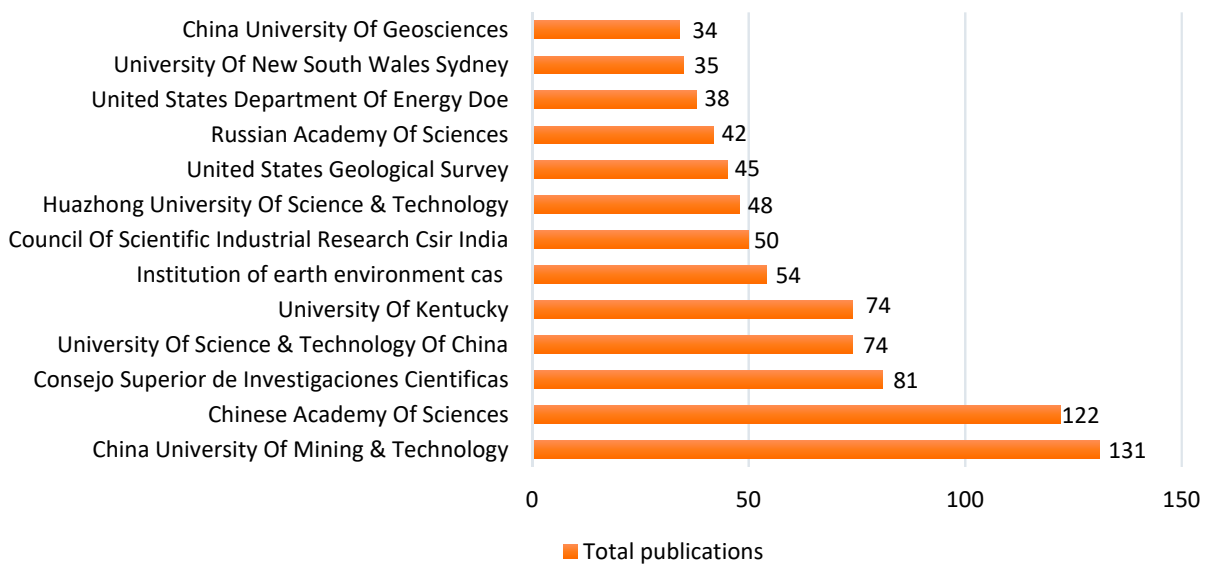

Figure 4. The total publications of the most productive institutions of trace elements in coal and ash.

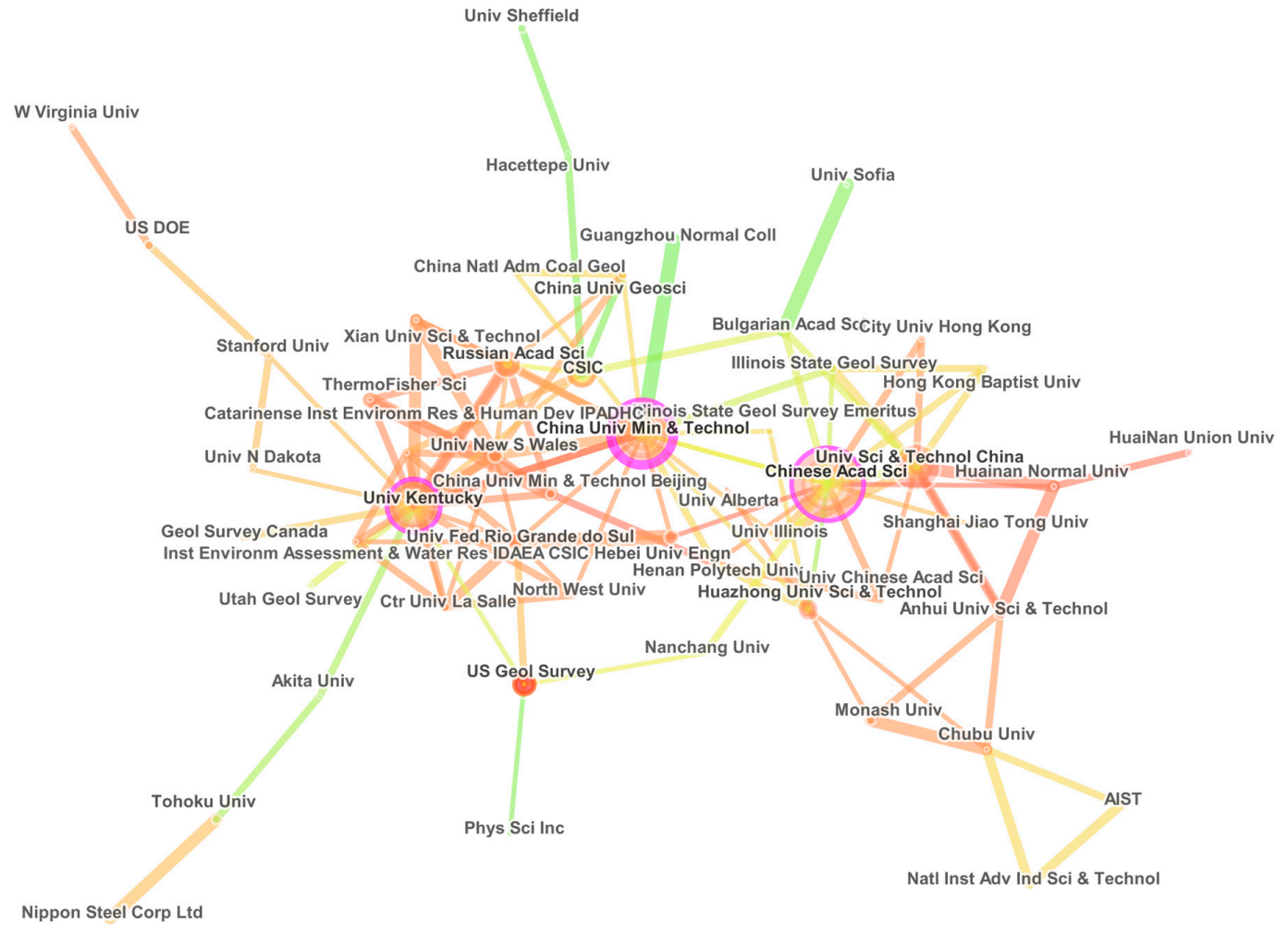

Figure 5. The cooperation network of the most productive institutions of trace elements in coal and ash. 


\subsection{Distribution of Discipline Types and Journals}

\subsubsection{Distribution of Discipline Types}

The discipline means academic classification, which refers to a specific scientific field or a branch of science. According to the discipline classification of Web of Science, there are 30 disciplines with more than five publications about the study on trace elements in coal and 14 disciplines with more than 30 publications of the same field. Among them, Energy and Fuels is the most productive key discipline, with 767 relevant publications, accounting for $45 \%$ of the total publications (Figure 6), followed by Engineering and Environmental Sciences and Ecology, accounting for 36\% and 31\% respectively, and Geology and Chemistry, accounting for $21 \%$ and $12 \%$ respectively. Other relevant disciplines account for less than 10\% (Figure 6). According to the quantity of publications, Energy Fuels, Engineering and Environmental Sciences and Ecology are key disciplines in terms of relevant publications about the study on trace elements in coal, and Geology, Chemistry, Mining and Mineral Processing, Toxicology, Water Resources and so forth are major disciplines, indicating that the trace elements in coal and ash will be widely applied in the future study, with strong interactivity with different disciplines.

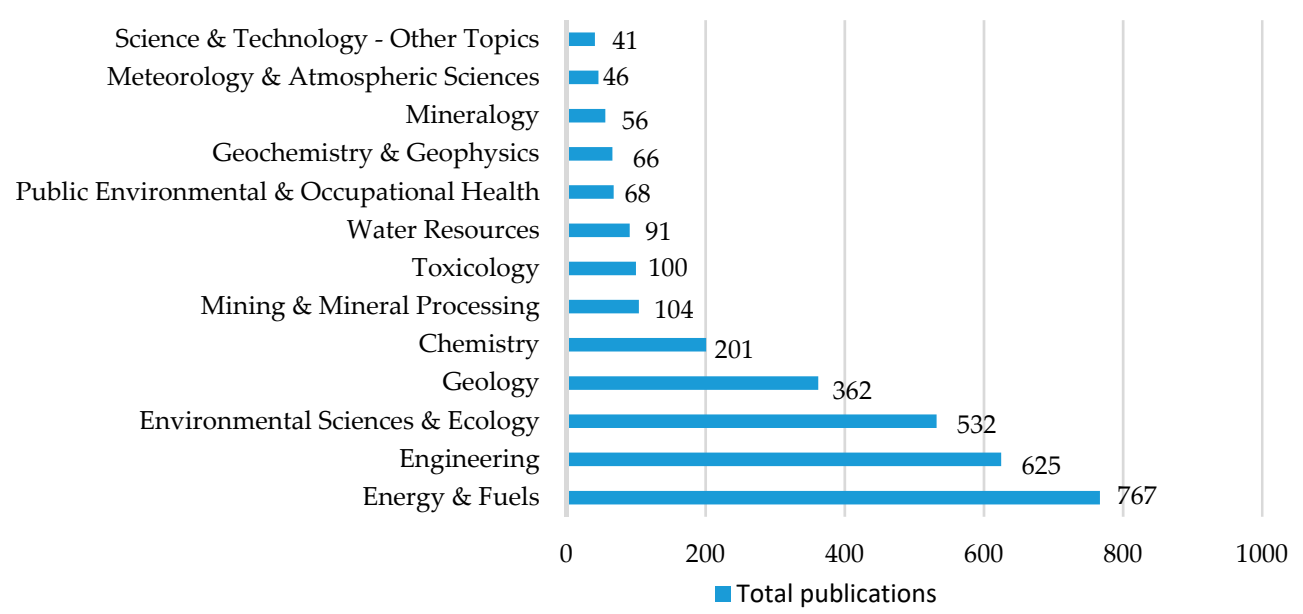

Figure 6. Publications of the most productive categories of trace elements in coal and ash.

Through comparative analysis, the disciplines of Chemistry, Energy and Fuels, Environmental Sciences and Ecology and Engineering rank at the top in terms of centrality. In combination with the TimeLine (Figure 7) generated by the hot disciplines regarding the study on trace elements in coal and through comprehensive analysis, from 1971-2017, Energy and Fuels started the study on trace elements in coal earlier, followed by Environmental Sciences and Ecology and Chemistry. Energy and Fuels, Engineering and Environmental Sciences and Ecology have always been hot disciplines regarding the study on trace elements in coal. Other disciplines entered into this field based on the study results of these hot disciplines. For example, the study on trace elements in coal of Geosciences and Geology is based on the study results of Energy and Fuels and Environmental Sciences, now more disciplines including Forestry, Agricultural and Toxicology have been involved. It indicates that the emerging disciplines could absorb the existing technical advantages of other disciplines in this field during expansion and sharing of their academic knowledge regarding the study on trace elements in coal, so as to promote their development. Moreover, they could use new technologies to tackle their key problems and play an important role in their expansion and penetration. 


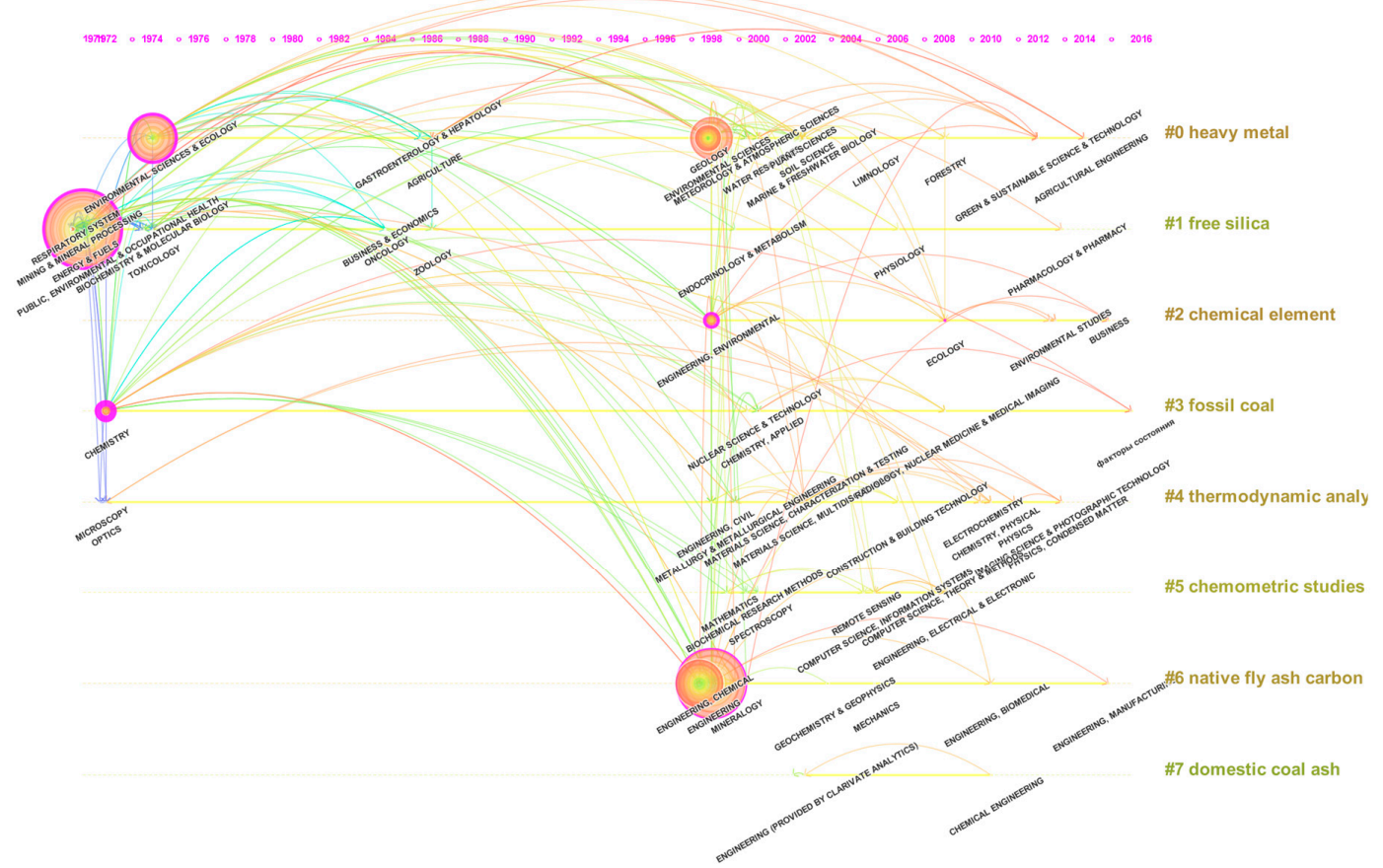

Figure 7. The TimeLine of categories of trace elements in coal and ash.

\subsubsection{Distribution of Journals}

The distribution of journals reflects the centrality of publications of a specific discipline to some extent. It is one of the important indicators for evaluation on the development level of the discipline. The search report generated by Web of Science indicates that from 1971 to 2017, 50 journals have more than five publications and 17 journals have 15 publications or more (Table 4). Among them, International Journal of Coal Geology $(230,13.34 \%)$ and Fuel $(158,9.17 \%)$ rank at the top, followed by Energy Fuels (87, 5.05\%), Fuel Processing Technology $(53,3.07 \%)$ and Environmental Science Technology $(43,2.5 \%)$. The results indicate that top five journals with the highest centrality are as follows: Chemical Geology (0.21), Geochimica et Cosmochimica Acta (0.14), International Journal of Coal Geology (0.08), Environmental Science Technology (0.08), Science (0.08) (see Table 4).

Table 4. Distributions of output in key journals of trace elements in coal and ash in 1971-2017.

\begin{tabular}{cccc}
\hline Journal & TP & IF (2017) & Centrality \\
\hline International Journal of Coal Geology & 230 & 4.783 & 0.08 \\
Fuel & 158 & 4.601 & 0.02 \\
Energy and Fuels & 87 & 3.091 & 0.05 \\
Fuel Processing Technology & 53 & 3.752 & 0.07 \\
Environmental Science and Technology & 43 & 6.198 & 0.08 \\
Energy Sources Part A Recovery Utilization and Environmental Effects & 38 & 0.527 & 0.02 \\
Environmental Monitoring and Assessment & 28 & 1.687 & 0.01 \\
Chemosphere & 26 & 4.208 & 0.06 \\
Journal of Hazardous Materials & 24 & 6.065 & 0.03 \\
Science of The Total Environment & 24 & 4.9 & 0.05 \\
Applied Geochemistry & 22 & 2.581 & 0.05 \\
Energy Exploration and Exploitation & 21 & 0.963 & 0.02 \\
Minerals & 20 & 2.088 & 0.01 \\
Environmental Earth Sciences & 19 & 1.569 & 0.00 \\
Environmental Geochemistry and Health & 18 & 2.616 & 0.04 \\
Environmental Science and Research & 18 & 2.467 & 0.01 \\
\hline TP: Total publistions
\end{tabular}

TP: Total publications; IF: Impact factor (2017). 
In terms of the quantity of publications, the proportion of top two journals is not high, accounting for only $22.51 \%$ of the total publications. Most of the publications come from other types of journals, reflecting the breadth of publication distribution and the broad study perspective of the study interests, as well as the penetration effect among different disciplines. In addition, according to the image factors of all journals in 2017, the influence factor of the journal is not directly proportional to its quantity of publications and cited frequency in the field of study on trace elements in coal and ash, therefore the influence of the journal in the study field cannot be judged by the influence factor alone.

\subsection{Study Focuses and Trends}

\subsubsection{Co-Occurrence of Keywords and Terms}

Studies indicate that, in addition to the search terms of trace elements and coal, mercury and emission have comparatively large nodes (Figure 8), and accordingly large centrality (Table 5), visible fly ash and coal combustion products are also focuses of this field. According to the dynamic evolution graph of keywords, environmental impact and health impact appeared successively in 2005 and 2008 (Figure 9), indicating that the study focus has changed from the properties of coal to the environment and human health. The node type selection conducts burst detection of keywords from 1999 to 2017 and develops the ordination diagram of the year of the keyword with strong burst (Table 6). The results indicate that the terms with strong burst are "mineral matter", followed by "coal-fired power plants" and "rare earth element". We can see from the above that the study of coal-fired power plants and rare earth elements are comparatively hot, with the burst term of "environmental concern" in 2006, environment becomes a hot issue.

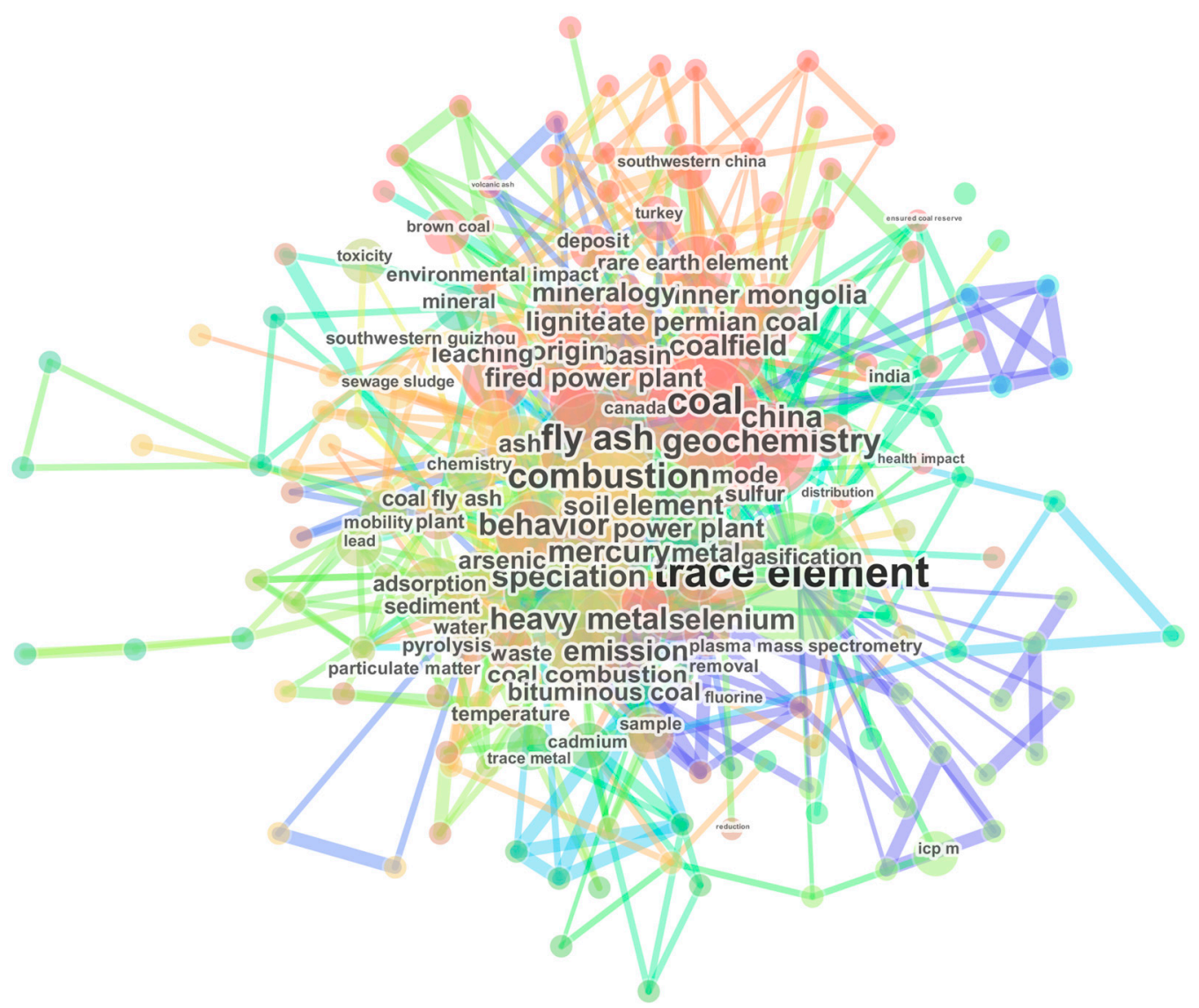

Figure 8. The co-occurrence of keywords of trace elements in coal and ash. 


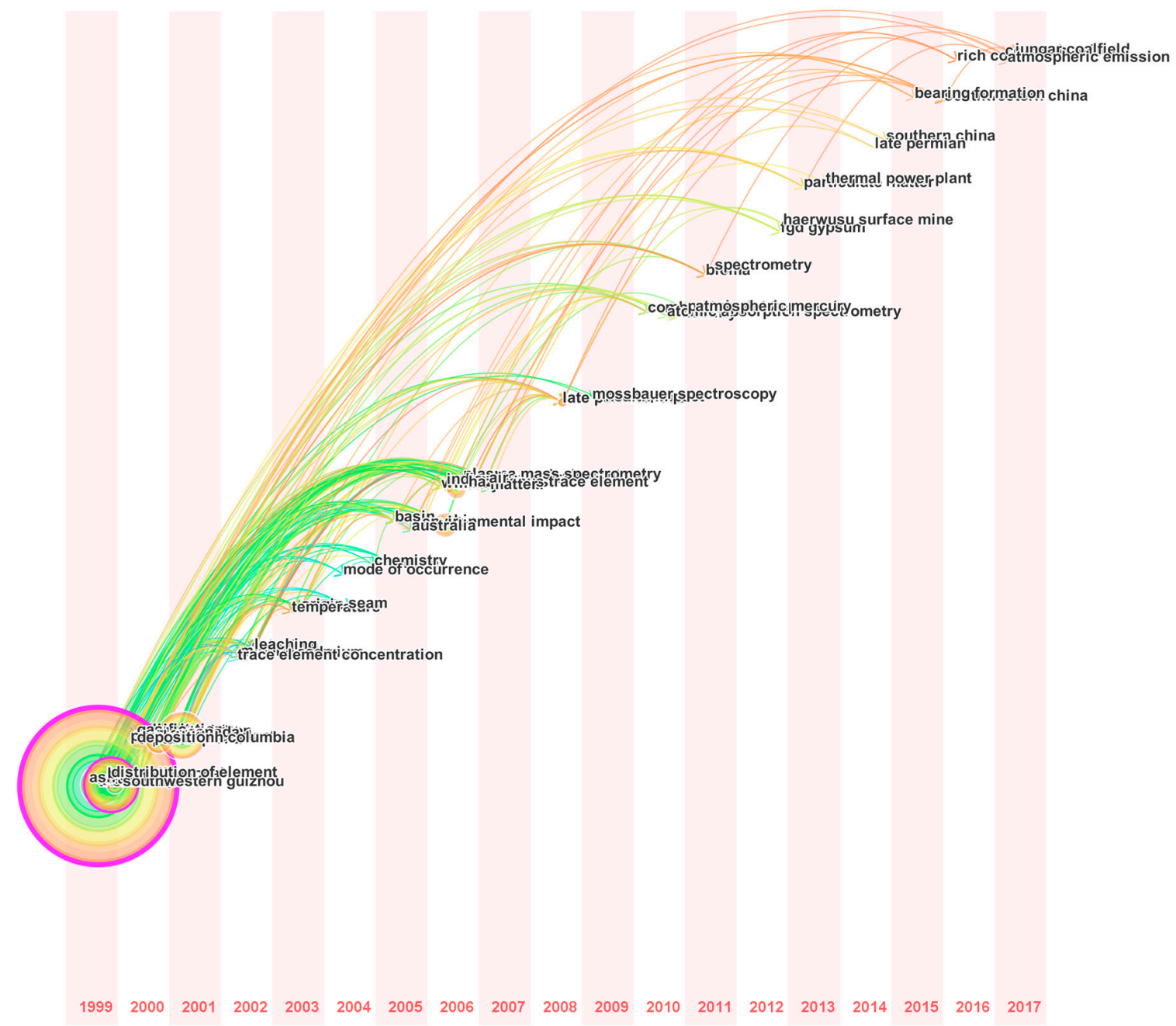

Figure 9. The TimeZone of keywords of trace elements in coal and ash.

Table 5. Characteristics by year of high frequency keywords of trace elements in coal and ash.

\begin{tabular}{cccc}
\hline Keywords & Frequency & Centrality & Year \\
\hline trace element & 425 & 0.25 & 1999 \\
coal & 177 & 0.15 & 1999 \\
fly ash & 171 & 0.1 & 2000 \\
combustion & 140 & 0.07 & 1999 \\
geochemistry & 98 & 0.07 & 2000 \\
behavior & 83 & 0.09 & 2000 \\
China & 81 & 0.05 & 2005 \\
mercury & 72 & 0.09 & 1999 \\
heavy metal & 70 & 0.06 & 2006 \\
speciation & 65 & 0.07 & 2000 \\
emission & 64 & 0.08 & 1999 \\
element & 51 & 0.04 & 2000 \\
selenium & 48 & 0.04 & 2002 \\
coalfield & 47 & 0.07 & 1999 \\
power plant & 42 & 0.03 & 2000 \\
fired power plant & 42 & 0.03 & 2000 \\
late permian coal & 41 & 0.06 & 2008 \\
soil & 39 & 0.02 & 1999 \\
metal & 38 & 0.04 & 2000 \\
inner mongolia & 37 & 0.07 & 2006 \\
mineralogy & 37 & 0.03 & 2002 \\
\hline
\end{tabular}


Table 6. Top 25 Terms with the Strongest Citation Bursts of trace elements in coal and ash in ascending order of Beginning years.

\begin{tabular}{|c|c|c|c|c|c|}
\hline Terms & Year & Strength & Begin & End & Range (1999-2017) \\
\hline mineral matter & 1999 & 7.7156 & 2000 & 2004 & 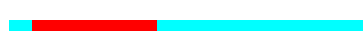 \\
\hline clay minerals & 1999 & 3.3762 & 2000 & 2002 & 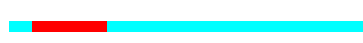 \\
\hline coal combustion & 1999 & 3.6944 & 2000 & 2004 & - \\
\hline fly ash & 1999 & 7.583 & 2002 & 2007 & 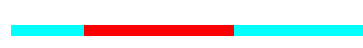 \\
\hline coal beds & 1999 & 3.0885 & 2003 & 2007 & 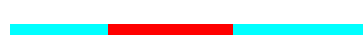 \\
\hline mosts element & 1999 & 3.9696 & 2005 & 2007 & \\
\hline environmental concern & 1999 & 4.1773 & 2006 & 2009 & \\
\hline Chinese coals & 1999 & 3.831 & 2007 & 2010 & \\
\hline leaching characteristic & 1999 & 3.533 & 2010 & 2013 & \\
\hline present work & 1999 & 3.0898 & 2010 & 2013 & \\
\hline coal-fired power plants & 1999 & 6.4782 & 2011 & 2014 & \\
\hline rare earth element & 1999 & 5.5985 & 2012 & 2017 & \\
\hline human health & 1999 & 4.8801 & 2012 & 2015 & \\
\hline X-ray diffraction & 1999 & 3.9832 & 2013 & 2017 & \\
\hline coal mining area & 1999 & 3.5646 & 2013 & 2017 & \\
\hline hazardous element & 1999 & 3.5598 & 2013 & 2014 & \\
\hline enrichment factor & 1999 & 4.0751 & 2014 & 2017 & \\
\hline coal gangue & 1999 & 4.0751 & 2014 & 2017 & \\
\hline toxic element & 1999 & 3.9001 & 2014 & 2017 & \\
\hline coal seam & 1999 & 7.1935 & 2014 & 2017 & 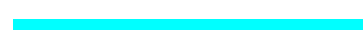 \\
\hline plasma mass spectrometry & 1999 & 3.4137 & 2014 & 2017 & 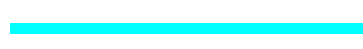 \\
\hline coal cleaning & 1999 & 3.1603 & 2014 & 2017 & \\
\hline heavy metals & 1999 & 4.9185 & 2015 & 2017 & \\
\hline
\end{tabular}

\subsubsection{Co-Citation Analysis of Publications}

The study results indicate that the most frequently cited publications are Ketris M.P. (2009) and Dai S.F. (2012), with the largest corresponding nodes in the graph, very high corresponding centrality and burst (see Figure 10). Although Dai S.F. (2005) is not frequently cited, it has high centrality, indicating that they have comparatively great influence. Although the citation frequency and centrality of Seredin V.V.(2012) is not high, it has strong burst (see Table 7), indicating that it has striking study results and high level of attention in 2012, and therefore it can be used as a reference for research focuses and trends.

Table 7. Characteristics of highly cited publications of trace elements in coal and ash during 1999-2017.

\begin{tabular}{ccccc}
\hline NO. & Publications & Frequency & Centrality & Burst \\
\hline 1 & Ketris M.P., 2009, INT J COAL GEOL, V78, P135 & 78 & 0.08 & 20.21 \\
2 & Dai S.F., 2012, INT J COAL GEOL, V94, P3 & 68 & 0.06 & 20.92 \\
3 & Dai S.F., 2008, INT J COAL GEOL, V74, P185 & 32 & 0.06 & 8.17 \\
4 & Mardon S.M., 2004,INT J COAL GEOL,V59,P153 & 24 & 0.05 & 7.4 \\
5 & Dai S.F., 2005, INT J COAL GEOL,V61,P119 & 23 & 0.12 & 7.54 \\
5 & Riley K.W., 2012, INT J COAL GEOL, V94, P214 & 23 & 0.02 & 7.84 \\
5 & Seredin V.V., 2012, INT J COAL GEOL, V94, P67 & 23 & 0.01 & 10.26 \\
5 & Jankowski J., 2006, FUEL, V85, P243 & 23 & 0.00 & 8.27 \\
\hline
\end{tabular}




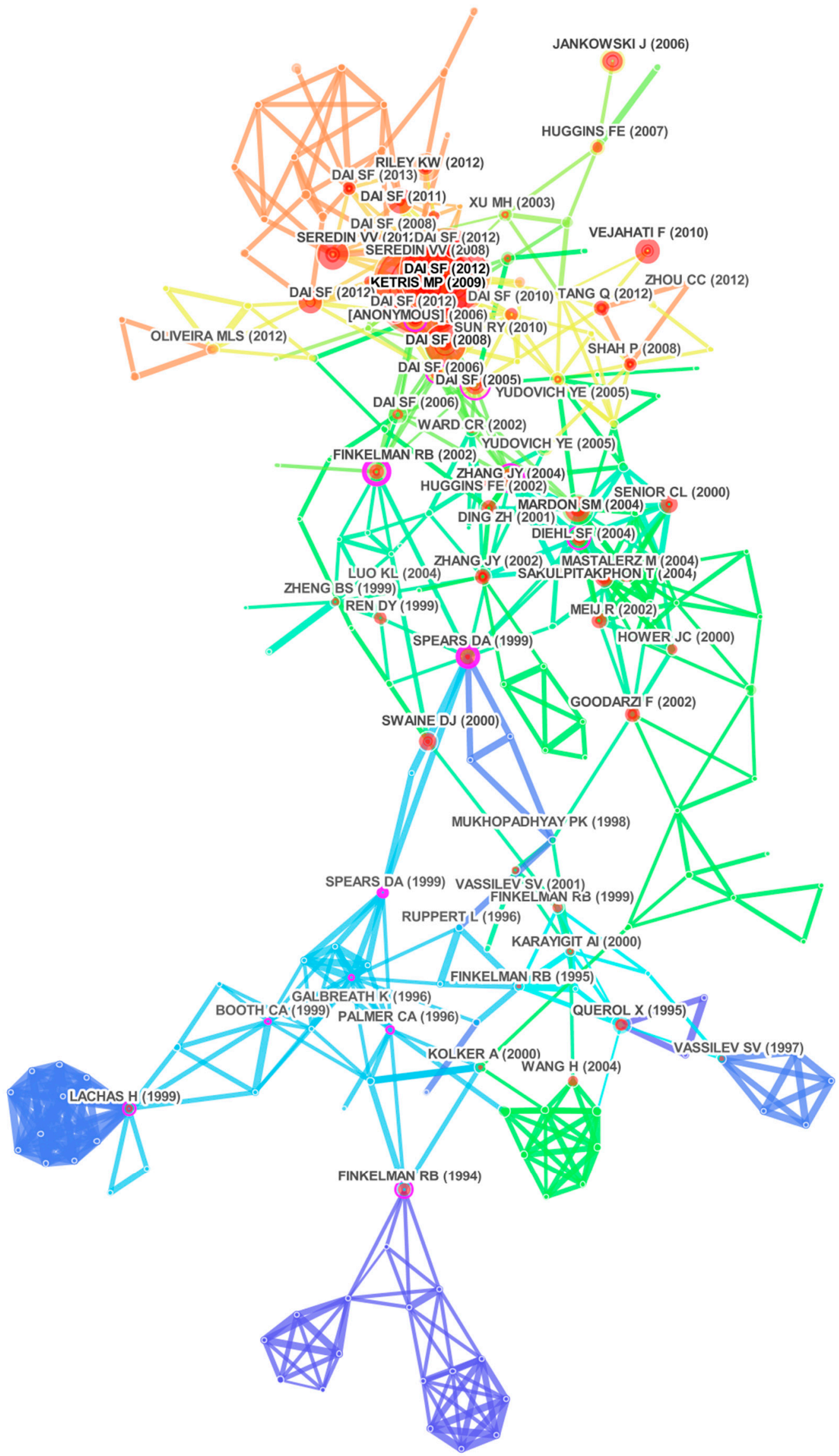

Figure 10. SNA (social network analysis) of highly cited publications of trace elements in coal and ash during 1999-2017. 


\subsubsection{Study Focuses and Frontier}

(1) Enrichment origin and modes of occurrence of trace elements in coal

The enrichment origin [26] and modes of occurrence [27,28] of trace elements in coal, especially those with highly environmental concerns such as $\mathrm{Hg}$, As, F [5,6] and Se, Te [29], and those with highly economic added values [30] such as $\mathrm{Ge}, \mathrm{Ga}, \mathrm{Nb}$ and rare earth elements [31-35] are strongly concerned. X-ray diffraction is a common method for determination of minerals related to toxic and valuable (critical) elements in coal [36] (see Table 6). The coal resources in different basin or areas and different geological ages are different [37,38], and the concentrations of trace elements in coal vary greatly, from less than ppb level (such as platinum group elements [39-41]) to several thousand ppm (such as As [5,42], Ge [43] and U [44]). Along with the development of the study, the enrichment area and coal bed of trace elements are gradually discovered. According to the key words, most of studies are about China, especially Inner Mongolia (see Figure 8). In terms of coal-forming age, the majority of studies are about the Late Permian. As a raw material of chemical industry, the study on migration and transformation of trace elements in coal during dressing and occurrence state changes of trace elements after gasification of raw material coal is widely adopted. The leaching experiment of coal combustion residues could be adopted to determine the content and migration regularity of trace elements. The modes of occurrence of trace elements could be inferred by the leaching characteristics of coal ash [45].

(2) The fly ash is generated by coal combustion

As coal is an important fuel for power generation, the coal combustion residues are the study focus today [46]. Fly ash is the main residue of coal combustion (usually accounting for 60-88\%) [47]. It is estimated that coal-fired power generation produces more than 750 metric tons of coal ash annually in the world. The trace elements in fly ash, no matter whether it is discharged into atmosphere, soil or water, will pollute the environment and have adverse impacts on human health. Now, fly ash is widely applied, including production of construction materials, asphalt concrete, stabilized soil of the pavement base, polymer and so on [48]. However, the human health problems caused by trace elements of fly ash in air, soil and water [49] cannot be avoided. These problems are highly concerned, including increase of particulate matter in the atmosphere generated by the coal-fired power plant [50], pollution of different degrees of water resources near the mining area, imbalance of elements including fluoride, selenium and arsenic in the underground water due to coal measure strata and human diseases caused by high trace elements content.

\subsubsection{Analysis of Study Trend}

The study trend refers to the field of term which arouses growing public interest and discussion and application by more and more scholars over time. The study trend of trace elements in coal in combination with the burst terms and frequently cited publications is as follows:

(1) Improvement of sampling technology and element determination method [51,52]. Although the concentration of trace elements in coal in some territories gradually become clear, distribution of samples in some areas are not uniform [53], and the determination of element adopts different methods. Therefore, errors are inevitable in the determination of the reserves and average levels of elements in different coal beds, and the determination of modes of occurrence of low concentration trace elements is difficult [54]. Improving the technology level of element determination will be one of the study trends.

(2) The extraction technology of valuable elements and the utilization value of fly ash [55]. As an important raw material of chemical industry in the world, coal features high consumption. The modes of occurrence, the extraction methods of critical elements, and the potential industrial use of fly ash will be the study trend in the future [56,57], e.g., the long-term challenge of capturing mercury from coal gas generated by the power plant [58]. 
(3) The impact on environment and human health. The waste generated before coal mining, during coal mining and storage, and during and after coal combustion is a well-known challenge [59-61]. The environmental problems, along with human health problems, caused by the above processes have attracted much public attention. The use of clean coal is becoming one of the key technologies to solve this problem in the future $[62,63]$.

\section{Conclusions}

This study adopts the bibliometric methods to discuss and analyze the study status quo, focuses and trends of trace elements in coal in terms of publications, authors, countries, institutions, disciplines and journals and so forth based on CiteSpace. It indicates that since the study of trace elements in coal started in 1991, this field has experienced a steady and slow development trend from 1991 to 1998, and the attention in this field began to rise rapidly in 1999. So far, the study results of trace elements in coal and ash have increased year by year. Shifeng Dai, Robert B Finkelman, Guijian Liu and James C Hower et al. have made comparatively great contributions to the field of study on trace elements in coal with strong influence. China and USA have high productivity in terms of total publications. Based on SNA analysis, China, USA, Australia, England and other highly productive countries cooperate closely; China University of Mining and Technology and Chinese Academy of Sciences are two most influential institutions in this field with the largest quantity of publications in terms of study on trace elements in coal and thus they take the leading position. The relevant studies on trace elements in coal mainly focus on the disciplines of Energy and Fuels, Engineering, Environmental Sciences and Ecology and involve Chemistry, Geology and other disciplines, with strong interdisciplinary characteristic. The International Journal of Coal Geology, Fuel, Energy and Fuels and Fuel Processing Technology are four major journals with the most prominent study achievements, largest quantity of publications and strong influence in the field of study on trace elements in coal and ash. According to the analysis of relevant study indicators, the enrichment origin and modes of occurrence of trace elements in coal is a study focus. The study on ions and nuclides of elements in different coal beds and detection method have promoted the study on trace elements in coal. The coal ash produced by coal combustion has always been a public concern, and thus the environmental pollution and human health problems caused by coal combustion will be the future study trend in this field.

The present study provides many interesting information in detail on trace elements in coal and ash quantitatively, however, there still exist some limitations. Firstly, because of the CiteSpace software's limitation, the publications in this database for analysis don't include the pioneering studies in print form. Secondly, the results are derived from the publications from 1971 to 2017, which will outdate in the future. This present study's main aim is to apply a new quantitative method to assess the literature, not same to the previous qualitative assessment. We will do further research in this field by narrow down the searching keywords and keep up with the new publications in the future.

Acknowledgments: This research is supported by the National Basic Research Program of China (973 Program, No. 2014CB238906). Many thanks to the Editorial staff of Minerals and the anonymous reviewers.

Author Contributions: Liu Yang and Qiqi Wang conceived and designed the study; Liu Yang and Xue Bai performed the software and analyzed the data; Jun Deng and Yinjie Hu contributed with materials and analysis tools; Liu Yang, Xue Bai and Qiqi Wang wrote the paper with contributions from Jun Deng and Yinjie Hu. All authors read and approved the manuscript.

Conflicts of Interest: The authors declare no conflict of interest.

\section{References}

1. Chen, J.; Liu, G.; Kang, Y.; Wu, B.; Sun, R.; Zhou, C.; Wu, D. Coal utilization in China: Environmental impacts and human health. Environ. Geochem. Health 2014, 36, 735-753. [CrossRef] [PubMed]

2. Dai, S.; Zhao, L.; Peng, S.; Chou, C.-L.; Wang, X.; Zhang, Y.; Li, D.; Sun, Y. Abundances and distribution of minerals and elements in high-alumina coal fly ash from the Jungar Power Plant, Inner Mongolia, China. Int. J. Coal Geol. 2010, 81, 320-332. [CrossRef] 
3. Zhang, S.; Liu, G.; Sun, R.; Wu, D. Health risk assessment of heavy metals in groundwater of coal mining area: A case study in Dingji coal mine, Huainan coalfield, China. Hum. Ecol. Risk Assess. Int. J. 2016, 22, 1469-1479. [CrossRef]

4. Fang, T.; Liu, G.; Zhou, C.; Lu, L. Lead in soil and agricultural products in the Huainan Coal Mining Area, Anhui, China: Levels, distribution, and health implications. Environ. Monit. Assess. 2015, 187, 152. [CrossRef] [PubMed]

5. Finkelman, R.B.; Tian, L. The health impacts of coal use in China. Int. Geol. Rev. 2017. [CrossRef]

6. Dai, S.; Li, W.; Tang, Y.; Zhang, Y.; Feng, P. The sources, pathway, and preventive measures for fluorosis in Zhijin County, Guizhou, China. Appl. Geochem. 2007, 22, 1017-1024. [CrossRef]

7. Carlberg, J.R.; Crable, J.V.; Limtiaca, L.P.; Norris, H.B.; Holtz, J.L.; Mauer, P.; Wolowicz, F.R. Total Dust, Coal, Free Silica, and Trace Metal Concentrations in Bituminous Coal Miners' Lungs. Am. Ind. Hyg. Assoc. J. 1971, 32, 432-440. [CrossRef] [PubMed]

8. Zhang, Y.; Huang, K.; Yu, Y.; Yang, B. Mapping of water footprint research: A bibliometric analysis during 2006-2015. J. Clean. Prod. 2017, 149, 70-79. [CrossRef]

9. Liu, Q.; Gui, J.; Yang, X.; Qu, Y. Research status and development trends for sensing and control technologies of industrial robot from the viewpoint of patent analysis. Robot 2016, 38, 612-620. (In Chinese)

10. Liang, Y.D.; Li, Y.; Zhao, J.; Wang, X.Y.; Zhu, H.Z.; Chen, X.H. Study of acupuncture for low back pain in recent 20 years: A bibliometric analysis via CiteSpace. J. Pain Res. 2017, 10, 951-964. [CrossRef] [PubMed]

11. Chen, C. CiteSpace II: Detecting and visualizing emerging trends and transient patterns in scientific literature. J. Am. Soc. Inf. Sci. Technol. 2006, 57, 359-377. [CrossRef]

12. Xie, P. Study of international anticancer research trends via co-word and document co-citation visualization analysis. Scientometrics 2015, 105, 611-622. [CrossRef]

13. Chen, C. Searching for intellectual turning points: Progressive knowledge domain visualization. Proc. Natl. Acad. Sci. USA 2004, 101, 5303-5310. [CrossRef] [PubMed]

14. Freeman, L.C. Centrality in social networks conceptual clarification. Soc. Netw. 1978, 1, 215-239. [CrossRef]

15. Chen, C.; Hu, Z.; Liu, S.; Tseng, H. Emerging trends in regenerative medicine: A scientometric analysis in CiteSpace. Expert Opin. Biol. Ther. 2012, 12, 593-608. [CrossRef] [PubMed]

16. Li, Y.; Wang, Y.; Rui, X.; Li, Y.; Li, Y.; Wang, H.; Zuo, J.; Tong, Y. Sources of Atmospheric Pollution: A Bibliometric Analysis. Scientometrics 2017, 112, 1025-1045. [CrossRef]

17. Kim, M.C.; Zhu, Y.; Chen, C. How are they different? A quantitative domain comparison of information visualization and data visualization (2000-2014). Scientometrics 2016, 107, 123-165. [CrossRef]

18. Kim, M.C.; Chen, C. A Scientometric review of emerging trends and new developments in recommendation systems. Scientometrics 2015, 104, 239-263. [CrossRef]

19. Chen, C.; Dubin, R.; Kim, M.C. Emerging trends and new developments in regenerative medicine: A scientometric update (2000-2014). Expert Opin. Biol. Ther. 2014, 14, 1295-1317. [CrossRef] [PubMed]

20. Yu, D.; Xu, Z.; Pedrycz, W.; Wang, W. Information sciences 1968-2016: A retrospective analysis with text mining and bibliometric. Inf. Sci. 2017, 418-419, 619-634. [CrossRef]

21. Xiao, F.; Li, C.; Sun, J.; Zhang, L. Knowledge domain and emerging trends in organic photovoltaic technology: A scientometric review based on CiteSpace analysis. Front. Chem. 2017, 5, 67. [CrossRef] [PubMed]

22. Zhang, S.; Mao, G.; Crittenden, J.; Liu, X.; Du, H. Groundwater remediation from the past to the future: A bibliometric analysis. Water Res. 2017, 119, 114-125. [CrossRef] [PubMed]

23. Fu, H.; Wang, M.; Ho, Y.S. Mapping of drinking water research: A bibliometric analysis of research output during 1992-2011. Sci. Total Environ. 2013, 443, 757-765. [CrossRef] [PubMed]

24. Gao, W.; Chen, Y.; Liu, Y.; Guo, H. Scientometric analysis of phosphorus research in eutrophic lakes. Scientometrics 2015, 102, 1951-1964. [CrossRef]

25. Wang, Q.; Yang, Z.; Yang, Y.; Long, C.; Li, H. A bibliometric analysis of research on the risk of engineering nanomaterials during 1999-2012. Sci. Total Environ. 2014, 473-474, 483-489. [CrossRef] [PubMed]

26. Spears, D.A.; Manzanares-Papayanopoulos, L.I.; Booth, C.A. The distribution and origin of trace elements in a UK coal; the importance of pyrite. Fuel 1999, 78, 1671-1677. [CrossRef]

27. Goodarzi, F. Mineralogy, elemental composition and modes of occurrence of elements in Canadian feed-coals. Fuel 2002, 81, 1199-1213. [CrossRef] 
28. Dai, S.; Zou, J.; Jiang, Y.; Ward, C.R.; Wang, X.; Li, T.; Xue, W.; Liu, S.; Tian, H.; Sun, X.; et al. Mineralogical and geochemical compositions of the Pennsylvanian coal in the Adaohai Mine, Daqingshan Coalfield, Inner Mongolia, China: Modes of occurrence and origin of diaspore, gorceixite, and ammonian illite. Int. J. Coal Geol. 2012, 94, 250-270. [CrossRef]

29. Bullock, L.; Parnell, J.; Perez, M.; Feldmann, J. Tellurium enrichment in Jurassic coal, Brora, Scotland. Minerals 2017, 7, 1-13. [CrossRef]

30. Seredin, V.V.; Dai, S. Coal deposits as potential alternative sources for lanthanides and yttrium. Int. J. Coal Geol. 2012, 94, 67-93. [CrossRef]

31. Hower, J.C.; Granite, E.J.; Mayfield, D.B.; Lewis, A.S.; Finkelman, R.B. Notes on contributions to the science of rare earth element enrichment in coal and coal combustion byproducts. Minerals 2016, 6, 32. [CrossRef]

32. Hower, J.C.; Eble, C.F.; Dai, S.; Belkin, H.E. Distribution of rare earth elements in eastern Kentucky coals: Indicators of multiple modes of enrichment? Int. J. Coal Geol. 2016, 160-161, 73-81. [CrossRef]

33. Kolker, A.; Scott, C.; Hower, J.C.; Vazquez, J.A.; Lopano, C.L.; Dai, S. Distribution of rare earth elements in coal combustion fly ash, determined by SHRIMP-RG ion microprobe. Int. J. Coal Geol. 2017, 184, 1-10. [CrossRef]

34. Dai, S.; Finkelman, R.B. Coal as a promising source of critical elements: Progress and future prospects. Int. J. Coal Geol. 2017. [CrossRef]

35. Dai, S.; Yan, X.; Ward, C.R.; Hower, J.C.; Zhao, L.; Wang, X.; Zhao, L.; Ren, D.; Finkelman, R.B. Valuable elements in Chinese coals: A review. Int. Geol. Rev. 2016. [CrossRef]

36. Huggins, F.E. Overview of analytical methods for inorganic constituents in coal. Int. J. Coal Geol. 2002, 50, 169-214. [CrossRef]

37. Ketris, M.P.; Yudovich, Y.E. Estimations of Clarkes for Carbonaceous biolithes: World averages for trace element contents in black shales and coals. Int. J. Coal Geol. 2009, 78, 135-148. [CrossRef]

38. Dai, S.; Li, D.; Chou, C.-L.; Zhao, L.; Zhang, Y.; Ren, D.; Ma, Y.; Sun, Y. Mineralogy and geochemistry of boehmite-rich coals: New insights from the Haerwusu Surface Mine, Jungar Coalfield, Inner Mongolia, China. Int. J. Coal Geol. 2008, 74, 185-202. [CrossRef]

39. Dai, S.; Ren, D.; Zhang, J.; Hou, X. Concentrations and origins of platinum group elements in Late Paleozoic coals of China. Int. J. Coal Geol. 2003, 55, 59-70. [CrossRef]

40. Finkelman, R.B.; Aruscavage, P.J. Concentration of some platinum-group metals in coal. Int. J. Coal Geol. 1981, 1, 95-99. [CrossRef]

41. Seredin, V.V.; Finkelman, R.B. Metalliferous coals: A review of the main genetic and geochemical types. Int. J. Coal Geol. 2008, 76, 253-289. [CrossRef]

42. Dai, S.; Ren, D.; Tang, Y.; Yue, M.; Hao, L. Concentration and distribution of elements in Late Permian coals from western Guizhou Province, China. Int. J. Coal Geol. 2005, 61, 119-137. [CrossRef]

43. Dai, S.; Wang, P.; Ward, C.R.; Tang, Y.; Song, X.; Jiang, J.; Hower, J.C.; Li, T.; Seredin, V.V.; Wagner, N.J.; et al. Elemental and mineralogical anomalies in the coal-hosted Ge ore deposit of Lincang, Yunnan, southwestern China: Key role of $\mathrm{N}_{2}-\mathrm{CO}_{2}$-mixed hydrothermal solutions. Int. J. Coal Geol. 2015, 152, 19-46. [CrossRef]

44. Dai, S.; Yang, J.; Ward, C.R.; Hower, J.C.; Liu, H.; Garrison, T.M.; French, D.; O'Keefe, J.M.K. Geochemical and mineralogical evidence for a coal-hosted uranium deposit in the Yili Basin, Xinjiang, northwestern China. Ore Geol. Rev. 2015, 70, 1-30. [CrossRef]

45. Singh, M.K.; Kumar, S.; Ratha, D. Physiochemical and leaching characteristics of fly and bottom ash. Energy Sour. Part A Recovery Util. Environ. Eff. 2016, 38, 2377-2382. [CrossRef]

46. Mardon, S.M.; Hower, J.C. Impact of coal properties on coal combustion by-product quality: Examples from a Kentucky power plant. Int. J. Coal Geol. 2004, 59, 153-169. [CrossRef]

47. Vassilev, S.V.; Vassileva, C.G. A new approach for the classification of coal fly ashes based on their origin, composition, properties, and behavior. Fuel 2007, 86, 1490-1512. [CrossRef]

48. Izquierdo, M.; Querol, X. Leaching behaviour of elements from coal combustion fly ash: An overview. Int. J. Coal Geol. 2012, 94, 54-66. [CrossRef]

49. Jankowski, J.; Ward, C.R.; French, D.; Groves, S. Mobility of trace elements from selected Australian fly ashes and its potential impact on aquatic ecosystems. Fuel 2006, 85, 243-256. [CrossRef]

50. Meij, R.; Winkel, H.T. The emissions and environmental impact of pm10 and trace elements from a modern coal-fired power plant equipped with ESP and wet FGD. Fuel Process. Technol. 2004, 85, 641-656. [CrossRef] 
51. Dai, S.; Song, W.; Zhao, L.; Li, X.; Hower, J.; Ward, C.R.; Wang, P.; Li, T.; Zheng, X.; Seredin, V.V.; et al. Determination of Boron in Coal Using Closed-Vessel Microwave Digestion and Inductively Coupled Plasma Mass Spectrometry (ICP-MS). Energy Fuels 2014, 28, 4517-4522. [CrossRef]

52. Li, X.; Dai, S.; Zhang, W.; Li, T.; Zheng, X.; Chen, W. Determination of As and Se in coal and coal combustion products using closed vessel microwave digestion and collision/reaction cell technology (CCT) of inductively coupled plasma mass spectrometry (ICP-MS). Int. J. Coal Geol. 2014, 124, 1-4. [CrossRef]

53. Dai, S.; Ren, D. Fluorine concentration of coals in China-An estimation considering coal reserves. Fuel 2006, 85, 929-935. [CrossRef]

54. Riley, K.W.; French, D.H.; Farrell, O.P.; Wood, R.A.; Huggins, F.E. Modes of occurrence of trace and minor elements in some Australian coals. Int. J. Coal Geol. 2012, 94, 214-224. [CrossRef]

55. Swaine, D.J. Why trace elements are important. Fuel Process. Technol. 2000, 65-66, 21-33. [CrossRef]

56. Dai, S.; Ren, D.; Chou, C.-L.; Finkelman, R.B.; Seredin, V.V.; Zhou, Y. Geochemistry of trace elements in Chinese coals: A review of abundances, genetic types, impacts on human health, and industrial utilization. Int. J. Coal Geol. 2012, 94, 3-21. [CrossRef]

57. Dai, S.; Seredin, V.V.; Ward, C.R.; Jiang, J.; Hower, J.C.; Song, X.; Jiang, Y.; Wang, X.; Gornostaeva, T.A.; $\mathrm{Li}, \mathrm{X}$; et al. Composition and modes of occurrence of minerals and elements in coal combustion products derived from high-Ge coals. Int. J. Coal Geol. 2013, 121, 79-97. [CrossRef]

58. Hower, J.C.; Senior, C.L.; Suuberg, E.M.; Hurt, R.H.; Wilcox, J.L.; Olson, E.S. Mercury capture by native fly ash carbons in coal-fired power plants. Prog. Energy Combust. Sci. 2010, 36, 510-529. [CrossRef] [PubMed]

59. Finkelman, R.B.; Orem, W.; Castranova, V.; Tatu, C.A.; Belkin, H.E.; Zheng, B.; Lerch, H.E.; Maharaj, S.V.; Bates, A.L. Health impacts of coal and coal use: Possible solutions. Int. J. Coal Geol. 2002, 50, 425-443. [CrossRef]

60. Dai, S.; Finkelman, R.B. Coal geology in China: An overview. Int. Geol. Rev. 2017. [CrossRef]

61. Zhao, Y.; Yang, J.; Ma, S.; Zhang, S.; Liu, H.; Gong, B.; Zhang, J.; Zheng, C. Emission controls of mercury and other trace elements during coal combustion in China: A review. Int. Geol. Rev. 2017. [CrossRef]

62. Thomas, D.J. Finding a future for clean coal and $\mathrm{CO}_{2}$ storage technology. Fuel 2017, 195, 314-315. [CrossRef]

63. Devasahayam, S.; Ameen, M.; Verheyen, T.; Bandyopadhyay, S. Brown Coal Dewatering using Poly (Acrylamide-Co-Potassium Acrylic) based super absorbent polymers. Minerals 2015, 5, 623-636. [CrossRef] 